\title{
Trajectories of mixed couples in Morocco: a meaningful discursive space for mixedness
}

\author{
Catherine Therrien \\ Moroccan Center of Social Sciences (CM2S) \\ catherinetherrien@yahoo.fr
}

Received: 17-11-2010

Accepted: 12-07-2011

\begin{abstract}
Based on an ethnographic study that puts narratives of experience and participant observation at the heart of its methodology, this article starts from the premise that the theoretical framework used in the social sciences to describe the experiences of mixedness is no longer adapted to contemporary situations of mobility. It is argued here that specific writings on mixed couples within the Moroccan context are constrained by a negative discursive habitus. By focusing on mixed couples' trajectories in the Moroccan context, this article contributes to the development of a conceptual framework reflecting current movement at the heart of this contemporary experience. Furthermore, the originality of this article lies mainly in the fact that it proposes to study conjugal mixedness from the perspective of the metaphor of prolonged travel. It will be argued that mixedness may be seen as a journey (full of negotiation and ambivalence) that offers possibilities for cultural enrichment and self-distanciation. This angle invites couples to open themselves up to a cultural transformation that begins well before their romantic encounter and that intensifies with migration. The emergence of this perspective is linked to the socio-political context in which this research came to light, and to my own specific posture as a researcher. In particular, it contributes to revitalizing the theoretical framework for looking at mixedness, helping to elaborate a positive discursive habitus concerning mixed unions.
\end{abstract}

Key words: ethnography; biographical trajectory; discursive habitus; home; mobility; prolonged travel; personal identity.

Resumen. Trayectorias de parejas mixtas en Marruecos: un espacio discursivo significativo para el mestizaje

Basado en un estudio etnográfico que pone la narración de la experiencia y la observación del participante en el centro de su metodología, este articulo se sustenta en la premisa que el marco teórico usado en las ciencias sociales para describir las experiencias del mestizaje ya no se adapta a la situaciones contemporáneas de movilidad. Se argumenta que la literatura específica sobre parejas mixtas en el contexto de Marruecos está constreñida por un hábito discursivo negativo. Centrándose en las trayectorias de las parejas mixtas en el contexto marroquí, este artículo contribuye al desarrollo de un marco conceptual que refleje el 
movimiento actual en el seno de esta experiencia contemporánea. Además, la originalidad de este artículo recae principalmente en el hecho de que propone el estudio del mestizaje conyugal desde la perspectiva de la metáfora de un viaje de largo recorrido. Se argumenta que el mestizaje pueda ser visto como un viaje (lleno de negociación y ambivalencia) que ofrece posibilidades de enriquecimiento cultural y auto-distanciación. Este punto de vista invita a las parejas a abrirse a una transformación cultural que empieza mucho antes de su encuentro romántico y que se intensifica con la migración. La emergencia de esta perspectiva está relacionada con el contexto socio-político en el que vio la luz esta investigación, y con mi propia postura como investigadora. En particular, contribuye a revitalizar la marco teórico teniendo en cuenta el mestizaje, y ayuda a elaborar un hábito de discurso positivo con relación a las uniones mixtas.

Palabras clave: etnografía; trayectoria biográfica; habitus discursif; hogar; movilidad; viaje prolongado; identidad personal.

\begin{tabular}{|c|c|}
\hline \multicolumn{2}{|c|}{ Summary } \\
\hline $\begin{array}{r}\text { Introduction } \\
\text { Methodological Approach }\end{array}$ & $\begin{array}{l}\text { Mixedness as a Possibility for Enrichment } \\
\text { and Self-Distanciation }\end{array}$ \\
\hline The Insider's Point of View & $\begin{array}{l}\text { Mixedness Resulting from a Trajectory } \\
\text { of Mobility }\end{array}$ \\
\hline tdated and Fixed Theoretical & $\begin{array}{l}\text { Mixedness as Invitation to Experience } \\
\text { Cultural Transformation }\end{array}$ \\
\hline $\begin{array}{r}\text { Framework } \\
\text { Vegative Discursive Habitus in }\end{array}$ & $\begin{array}{l}\text { Migration as an Intensification } \\
\text { of the Journey }\end{array}$ \\
\hline Mixed Couples in Morocco & Conclusion \\
\hline $\begin{array}{l}\text { specific Context of Morocco } \\
\text { gement upon the Moroccan }\end{array}$ & Bibliographic references \\
\hline
\end{tabular}

Rules of Social Cohesion

«L'arbre a des racines. Les hommes des jambes.

C'est une longueur d'avance"

Georges Steiner

\section{Introduction}

Anthropological inquiry is a pertinent methodology for dealing with social actors whose daily lives are negotiated at the crossroads of different cultural references. Many conceptual developments in the social sciences that have grappled with modern social transformations have focused on movement and mobility as the hallmarks of the contemporary world. ${ }^{1}$ Yet, if we consider theories developed to understand mixed couples, we find that such

1. Alemand (2004), Fernandez (2002), Tarrius (2002), Bauman (2001, 1996), Hoffman (1999), Knafou (1998), Clifford (1997), Appadurai (1996), Hannerz (1996), Bouvier (1995), Glick Schiller et al. (1995), Marcus (1995), Chambers (1994), Gupta and Ferguson (1992). 
approaches are not only often outdated, but fail to consider the movement inherent in experiences of mixedness. While dealing with the trajectories of mixed couples, this article contributes to the development of new language to describe these encounters. It takes into account the movement present at the core of this experience, all the while remaining specific to the context of mixed couples in Morocco.

This article presents a synthesis of a study conducted on mixed couples in Morocco, and summarizes the new theoretical perspective that structured its analytical approach. In addition to explaining the theoretical and methodological framework, I will argue that mixedness can be seen as a journey ${ }^{2}$ that offers possibilities for cultural enrichment and self-distanciation. Seen in this light, conjugal mixedness invites couples to open themselves up to cultural transformation, embarking on a journey that begins well before their romantic encounter and intensifies with migration. The ethnographic material from which this line of analysis emerged also reveals that mixedness is a journey full of ambivalence.

This article is, in some ways, a response to the observation made by Gabrielle Varro (2008) regarding an absence of a positive discursive habitus ${ }^{3}$ on the subject of conjugal mixedness aside from the discourse of voluntary associations who struggle for its acceptance. Attacking some of the paradigms thought to be resolutely negative is a new and a necessary step in order to renew the language and terminology, and to make a significant scientific contribution to this domain of research.

Before situating my theoretical approach in this article, I would like to clarify my research methods and to present a self-critical look at my specific position as a researcher.

\section{Methodological Approach}

A biographical approach has seemed to be the most appropriate way to handle the trajectories of mixed couples. To this end, I gathered life-course interviews from thirty-one couples (fifty-two individuals in total: thirty-one women and twenty-one men). I encountered individuals whose experiences differed in terms of several criteria: nationality, ${ }^{4}$ age, socio-economic class, religion, social status, family situation, how long the couple had been together, how long they had lived in Morocco, and so forth.

Participant observation also played an important role in the study, since living in Morocco and being part of a mixed couple myself allowed me to fre-

2. Journey understood here as an experience of distancing oneself from the 'home' of one's childhood.

3. Varro (1999) defines this notion of negative discursive habitus as the repetitive aspect of a discourse that is usually negative. It was originally employed in a text focusing on children of foreigners or of foreign origins in French public schools.

4. Foreign partners came from 15 different countries: the United States of America, Canada, France, Germany, Spain, Portugal, Russia, the Czech Republic, Iran, Japan, India, Vietnam, and Senegal. 
quently encounter research participants in casual situations. The life-course interviews allowed me to develop friendly connections with several couples. Following the life-course interviews, I frequently visited these couples (and their families), speaking with them on a more intimate level. I was witness to their questions, their conflicts, their happy moments, their sad times, their legal and bureaucratic wranglings, and much more. This proximity gave me access to their daily lives in a more personal way, something that allowed me to experience very informative moments with them. Living in Morocco also increased my opportunities for informal encounters. I had the occasion to speak with over a hundred individuals who felt involved in the subject of my study in one way or another.

\section{The Insider's Point of View}

From an anthropological angle, my position as an immigrant researcher offers several advantages. First, there is the fact of having lived for almost ten years in the heart of the target research area that has allowed me to become linguistically fluent in Moroccan Arabic. Secondly, I was considered by all the research participants as an insider, an immigrant just like them (for those who were non-Moroccan), and as a member of a Moroccan family (for those seeing me from the Moroccan perspective). Connections with research participants were, therefore, constructed from the very beginning on a basis of common ground and through sharing a sense of closeness.

My own personal experience involving mixed couples has also placed me in a privileged position as an anthropologist, offering me an authentic and select position, and not one that is merely symbolically attributed. In Morocco, I am a researcher, but I am also a wife, a mother, a daughter-in-law, a mrat would rti. ${ }^{5}$ am therefore living in situations that are uncommon for a foreign researcher. These have included having to go through the administrative processes to get married, enroll in a different healthcare system, receive family guests for my children's baptism accompanied by harira ${ }^{6}$ and a slaughtered sheep, enroll my children in Moroccan schools, consult notaries to resolve issues of inheritance, and attend the funeral of an in-law. This real and selfchosen position not only places me in a privileged point of observation, but also gives me an entry-way into a whole other way of life, access to knowledge that is not only intellectual, but also experiential, because it is of the body, of experiences and of emotions (Hastrup, 1995). The unity between the corporal experience and the intellectual aspect of research both invites and emphasizes reflection on the notion of researcher involvement within scientific investigation, a topic that I have explored elsewhere (Therrien, 2008).

In this shared experience I was also constantly torn between a position of being close, and a necessarily distant one of professionalism (leaving me in the delicate position of insider-outsider). Nevertheless, it was a springboard that

5. From my Moroccan husband's maternal uncle's point of view, I am his sister's son's wife.

6. Traditional tomato-based soup with flour and chickpeas. 
facilitated and enriched the research process, while preventing me from falling victim to excessive analytical emphasis simply on categorizations.

Before discussing my theoretical framework for mixedness, it is important to define what other researchers have understood by the term "mixed couple".

\section{Definition of "Mixed Couples"}

Streiff-Fenart's definition has the advantage of clarity: "What categorizes a type of marriage as mixed is the marking of borders" (Streiff-Fenart, 2000:16). A union is therefore defined as mixed when it transgresses a collective norm, a boundary understood not in a geographical sense, but in a symbolic one.

From an anthropological perspective, mixedness refers to exogamy, i.e. a transgression of endogamous matrimonial norms. This explains why anthropologists interested in mixedness tend to linger on the construction/delimitation of symbolic borders (Waldis and Bryon in Switzerland [2006]; Meintel and her team in Canada [2008, 2005 et 2002]; Dan Rodriguez in Spain [2006]; Breger and Hill in the United States [1998]).

It is important to underline the virtual and polysemic character of the term. Researchers agree that the notion actually takes on different meanings depending on the time, the place, and the context in which it occurs. Mixed unions are not, therefore, objective facts. They depend on the point of view of their observers and of the actors involved (Varro, 1995). A couple will be mixed depending on the time and place where boundaries are drawn.

\section{An Outdated and Fixed Theoretical Framework}

While surveying the scientific literature pertaining to mixed couples, I first found that the bulk of material provided insight from an outdated analytical framework. On the one hand, there is the compensatory exchange theory (Pineault, 2000; Breger and Hill, 1998; Spickard, 1989; Desruisseaux, 1990) that is based on the idea that marriage is a system of exchange. It is used to explain, for example, why a rich black man may aspire to marry a white, middle-class woman. There is also the assimilationist perspective (Rocheron, 1999; Streiff-Fenart, 1993; Leblanc, 1991; Bensimon and Lautman, 1975), which interprets mixed couples as an indication of the degree of immigrant assimiliation into a society. Sociological factors are used to explain the influence of social structures, often seen to outweight the choices of individuals. ${ }^{7}$

7. Some examples are: The explanation of inter-cultural unions as a normal consequence of mixing among the population (Cottrell, 1990; Imamura, 1990; Desruisseaux, 1990); the imbalanced sex-ratio theory developed by Peter Blau in the early 1970's (Spickard, 1989 and Root, 2001) that suggests that in places where the number of men and women are not equal, there will be more mixed marriages; the theory of mixed marriages as a social experiment (Barbara, 1993; Delcroix, 1993) that harbors a wholistic and homogenous vision of culture; and the approach taken by Streiff-Fenart (1989) that focuses on the economic and social conditions that allow a couple to make their mixedness a great resource. 
In some studies, the emphasis is placed on the instrumentalization of marriage (Neyrand, 1998). Meanwhile, in others it is placed on the psychological and psycho-analytical, proposing a vision of the mixed couple as deviant phenomenon, abnormal, even pathological (Vinsonneau, 1985; Tico, 1998; Krzywkowski and Djaoui, 1975). Of course, when authors mention these perspectives it does not mean they actually endorse them; but it shows that these perspectives were at the time in the forefront of theoretical elaborations.

None of these theories strike me as providing satisfactory analytical avenues. I agree with Varro (2003) when she asserts that these theories leave little room for the individual, for personal development, for creativity, and I would add, for movement. Nevertheless, most of the authors mentioned develop complex points of view on mixedness, leaving little room for oversimplification.

In recent years, new theories have emerged. We talk about mixed couples reflecting a pluralist society (Meintel, 2002), of creative incorporation (Breger and Hill, 1998), of love as a force for change (Root, 2001). Mixed couples are increasingly portrayed in a positive light and even as a source of enrichment. Some recent sociological writings expound on a perspective centered more on the individual (Collet and Philippe; 2008; Collet and Santelli, 2003; Varro, 2003; Fenoglio, 1999; Philippe, 1999). These new theoretical perspectives place emphasis on the individual, on experience and biographical identity, allowing us to describe the contemporary situation with greater nuance and finesse. This article falls in line with this theoretical perspective, which accounts for the point of view of the experiences of the social actors.

\section{A Negative Discursive Habitus in Writings on Mixed Couples in Morocco}

This article addresses mixed couples in the contemporary context of Morocco, dealing specifically with couples consisting of a foreign national and a Moroccan citizen that have chosen to establish themselves in Morocco. Even though a number of studies have been carried out on foreigner-Maghrebi couples in the European context, foreigner-Moroccan couples who have chosen to live in Morocco and have a very specific experience of their mixedness, have not yet been the subject of study in the social sciences.

Except for Addidou's master's thesis (1990), that reveals radical changes of values among mixed couples with relation to traditional Moroccan society and the praise of marital differences by the psycho-analyst Chbani Kunda (1990), the few studies in the social sciences dedicated to marital mixedness in the Moroccan context emphasize a trajectory of struggle (social and legislative) and of the difficulties that can arise for such couples (Ltaief, 2005; GRIC, 2003; Guiga, 1993; Manaf, 1990; Ben Arkoun, 1977).

An article by the Islamic-Christian Research Group of Rabat (GRIC, 2003), to take one example, raises questions about important and pertinent themes (i.e. the status of women, the patriarchal reality, the violence of conversion, human rights, religious kinship on the father's side, and so forth). 
Nevertheless, it contributes to producing a pejorative portrait of mixedness in the Morrocan context (the text addresses undeniable dramas, sufferings, anxieties, and feelings of exclusion, impurity, the accumulation of subtle forms of violence, of a captive situation, and scandal).

It is actually journalists (Alami, 2004; Daïf, 2003; Abdelghani, 2001) above all, who have been interested in mixed couples in Morocco, their articles focusing mainly on the difficulties that these couples may face. ${ }^{8}$ Their articles evoke unhappy marriages, high-risk love, daily challenges, the reservations of Moroccan in-laws, among other things. For their part, researchers who have been interested in conjugal mixedness in the Moroccan literature (BenzakourChami, 1990; Déjeux, 1989), depict an image of mixed couples that is cast in a clearly negative light.

On the whole, the little that has been written on the subject of mixed couples in the Moroccan context clearly contributes to the establishment of what Gabrielle Varro has called a negative discursive habitus with regards to conjugal mixedness.

This pessimism concerning mixed couples is nothing new. In the Moroccan context, mixed couples have often elicited more criticism than praise (StreiffFenart, 2000; Monkachi, 1990; Déjeux, 1989). Even though there is currently a greater acceptance of mixed unions in Morocco, these couples continue to represent a minority that is seen to threaten Moroccan social cohesion. Some examples on the context may help clarify this statement.

\section{The Specific Context of Morocco}

A Maghrebi country situated in the north of the African continent, Morocco is only separated from Spain by the few kilometers that make up the Strait of Gibraltar. It is a veritable mosaic geographically (seas, mountains, deserts, plains), socially (the socio-economic divide being remarkable), and culturally (Arabs, Berbers, Jews, and foreigners living together). In this Muslim monarchy, traditionally endogamous and patriarchal, the family represents the fundamental unit of the country's social and economic organization. Marriage remains the only legal way to form a legitimate couple; it is the only type of union accepted legally, religiously, and culturally.

To fully understand the context of mixedness in Morocco, it is first necessary to note that over the course of the last several decades, the introduction of new social models, and the cohabitation with and confrontation between new cultures contributed, notably during the time of the Protectorate (19231956), to modifying the Moroccan social landscape. These factors upset the traditional bases, produced the westernization of lifestyle, the individualization of the social sphere, and so forth (Lagnaoui, 1999; Belarbi, 1990). Social rules have been disrupted by industrialization, urbanization, education, de-tribali-

8. Several Arabic-language journals publish, from time to time, reports on mixed marriage that often deal with "the dangers of mixed marriages". 
zation, and the national movement which has contributed to the emergence of a new category of urban women: literate and employed. All of these changes have led to modifying the age of marriage, impacting the freedom to choose a partner, the formation and development of the restricted family, family planning, and the evolution of gender relations (Barraud, 2008; Bouasria, 2008; Le Briss, 2008). Major reforms (those of the Family Code ${ }^{9}$ and National Code ${ }^{10}$ ) significantly changed the Moroccan legislative context.

\section{An Infringement upon the Moroccan Rules of Social Cohesion}

It is because they transgress symbolic borders and/or legal ones that mixed unions disturb Moroccan society, obliging it to incorporate non-conforming elements into its traditional model (which is endogamous, Muslim and patriarchal). When an outsider enters a group, social cohesion comes into play, and a whole system of social controls (normative and legislative) is deployed to preserve the group's identity. Since what qualifies a couple as mixed is that it marks boundaries, a first stage at the time of my analysis consisted in identifying the delimitation of boundaries (legal and symbolic) in the Moroccan context. This involved uncovering aspects or key moments of the demarcation of boundaries as they are made visible by different reactions to mixedness. In Morocco, the establishment of boundaries can be perceived in a number of contexts, including: the legislation regarding mixed unions, where the main goal is to preserve the Islamic nature of the country; the welcome (or lack thereof) shown to the foreigner and the reactions of extended kin when he or she becomes a member of the family; and decisions as prospective parents concerning the upbringing of children in relation to mixed identities.

Let us consider the first point. A number of the legislative barriers that mixed couples face in Morocco revolve around an expectation of conversion to Islam. This is an obligatory condition in order for a male foreigner to sign a marriage act with a Muslim woman, as well as for ease in obtaining custody of children or Moroccan citizenship, inheritance, the adoption of a child, and so forth. However, when comparing legal texts with the reality of mixed couples in Morocco, my study brought to light the existing gap between what the law dictates, and the way that people adapt to it. This is possible to observe even when the law is apparently quite rigid, because social actors (as much the

9. In his role as Amir Mouminie (Commander of the Believers) King Mohammed VI revealed the new Family Code in October 2003. The new Code establishes equality within the family, with mutual responsibility. The family is placed under shared tutelage of two spouses. This Code marks the end of guardianship (wilaya): henceforth women of age can marry with or without approval of a guardian. The minimum age for marriage is the same for woman and men (eighteen years old). Heavy restrictions now make polygamy nearly impossible. Marital procedures for expatriates have been simplified. Consensual divorce has been instituted, etc.

10. The Code of Nationality reform, which took effect in 2007 , now permits the transmission of Moroccan citizenship from the mother. Before this new law that has had a considerable impact on mixed couples took affect, only the father could transmit Moroccan citizenship. 
individuals in mixed couples, and the people who have the power to enforce the law) know how to exercise flexibility.

Analysis of interviews treating the first encounters of couples and the beginnings of their relationships, also show that upon first speaking about their romantic alliances with their families, couples often realized the extent to which having made a different life choice revealed its greater implications. Through different reactions (which ranged from curiosity to threats of violence, to a warm welcome, and denial), couples realized that they were transgressing certain boundaries. For some, this was an entirely new realization. We observe that mixedness tends to upset and disturb close family members, because it also implies for them an intimate encounter with a foreign person. While mixedness was a choice for the couples, their unions imposed an openmindedness on close kin who did not always share the same approach towards foreigners. Nonetheless, field data shows that among mixed couples and their families, relationships are not always fixed and vary enormously over time. There can be periods of discomfort, coldness, conflicts, a distance created, a break (definitive or temporary), a reconciliation, resuming contact, regret about initial reactions, and eventually harmonious relationships.

While mixed unions disconcert many in Moroccan society, it is very likely because they carry with them the eventuality of children, which present new stakes in the transmission of cultural and national legacies. To accept and respect the differences of a foreign person, and to desire to transmit part of oneself to one's child, are two very different realities. The first, involving merely the mixed couple, is the choice of individuals, with no fusion or synthesis of differences necessarily taking place. By contrast, the arrival of a child transforms what is a choice of individuals into an intersection of cultural points of reference. This can plunge partners and their families into self-doubt about their own attitudes to culture, principles, values, traditions, and beliefs, obliging them to formulate plans as parents regarding their children's evolving social identities. It implies a negotiation between partners, as well as with extended families. The naming of children, the selection of places for socialization, the transmission of one or more nationalities, the transmission of one or more languages, the transmission of one or more religions, all become topics of negotiation. These can bring about tensions, but over the course of this study, it was equally fascinating to observe the fluidity and the openness that couples displayed.

Confronting the question of social boundaries, these couples revealed how they determine their own "territories", and the manner in which they manage this is decisive. In fact, this study illustrates that the context and the reception by the surrounding family have an important impact on the lives of mixed couples in Morocco. Nevertheless, the ways in which each couple adapts to the context (social and familial), and in which they set their own limits, play a key role with regards to the quality of their relationships both within the couple and within the extended family.

I previously brought up the fact that viewing mixedness as an extended journey allowed me to propose a new perspective which has structured my 
analysis here. The following section will detail different avenues of analysis in this vein.

\section{Mixedness as a Possibility for Enrichment and Self-Distanciation}

Field observations and the biographical narratives collected brought forth a first line of analysis: mixedness is a journey that opens onto the possibility of cultural enrichment and that permits one to distance onself from a childhood "home".

When I started observing mixed couples in their everyday lives, a similarity emerged: all of these couples shared the distinction of negotiating their dayto-day lives at the intersection of different cultural references. These related to the words they used (language), their sense of belonging (nationality), religion, ethnic identity, ways of being, of thinking and acting that are specific to a culture (table manners, gestures and body language, conceptions of time, of space, intimacy, etc.), references that are not always shared by members of a couple.

A few examples of the negotiation of cultural references include: a Senegalese man who spoke to his Moroccan wife in a language other than his native tongue; adjustments made to family meal times in a French-Moroccan household, where not everyone would fast during the month of Ramadan; the slaughtering of a sheep, a family tradition for a Moroccan man, but completely disgusting to his Asian partner; and the break-up of a Polish-Moroccan couple due to the indecisiveness about where to bury their child, who had died at a young age.

The majority of participants in the research tended to agree that their mixedness is a source of enrichment within their partnership and for their family. To live every day at the crossroads between different cultural references put mixed couples in a situation of permanent negotiation.. Nevertheless, this opened for them a vast cultural universe, it expanded their horizons, offering them more choices and obliging them to take into account new dimensions of social life, and to compare them.

Inès: I find it more exciting to not be exactly alike. It's more frustrating when we are on the same plane, with the same habits, the same words, the same references, its frankly frustrating... [...] Really, these differences have enriched my life. And when we say that we don't feel it, that is to say, that we don't suffer for it, at the same time it's there, you know.

(Inès is a forty-six year old Moroccan who has been living for five years in a mixed couple. She has a child from a prevoius marriage).

On this point, the field data echo new theoretical perspectives that highlight a positive vision of mixedness (Varro, 2003; Meintel, 2002; Fenoglio, 1999; Philippe, 1999; Breger and Hill, 1998; Dugan, 1997).

Analysis of these families' lifestyles reveal just how original they truly are. Observation of their day-to-day lives confirms that mixedness allows couples the opportunity to construct an original existence, drawing from a wide range 
of available cultural references. Different cultural configurations observed in the field ${ }^{11}$ are not simply a heterogeneous collage of pre-existing cultural elements. They open onto a third space (Bhabha, 1996), that is not merely an addition or a fusion between two cultures, but a new space created from laying out available cultural references that give way to an entirely new reality : mixedness.

Indeed, because mixedness creates a new model for drawing references from multiple cultural backgrounds, it provides couples an environment of creativity. For some, creativity is their goal. They find, within this mixed environment, a chance to live a very distinctive and original way of life. For others, it is this experience of mixedness which forces them to be creative. They have learned by necessity to construct an everyday existence at the intersection of different cultural references.

Such mixedness also affords these couples a sense of freedom. They have the opportunity to get away from their experiences, cultural models, and the anchors of their socialization, to build on the new, to forge a novel path, to decide for themselves what the configuration of their daily lives will be. These couples demand, not always in words but in the construction of their daily existence, the right to think and reflect before imitating and reproducing existing models, to live outside a pre-established mold.

Mixedness also provides the opportunity to distance oneself from his or her original reference model of "home", ${ }^{12}$ paving the way for the construction of a new self-identity. In accounts by couples of their lives, we clearly see a desire and willingness on their part to create their own trajectories, their own self-identities.

It is interesting to note that even the Moroccan partners, who have either remained in or returned to their homeland, have also moved away from their sense of "home". Anouar spoke Spanish at home; Houria did not have her son circumcised; Slimane celebrated Christmas with his child, even when Anna was not present; and Omar, despite being a Muslim, stopped slaughtering

11. A mix of two cultural models; a mode of cosmopolitan life; the common value-ing of a cultural model; a way of religious life; a cultural no man's land; the domination of one cultural model over the other.

12. The concept of "home", inspired by many authors (Schütz, 2003; Hoffman, 1999; Lagnaoui, 1999; Begag and Chaouite, 1999; Bachelard, 1957) does not refer as much to the physical place or places where we have lived (the house), as much as to an identity (home), being much more than a set of four walls and a roof over our heads. According to Hoffman (1999), the concept of "home" refers to an imaginary center. There are apparently two distinct homes. The one in the beginning, the home of our childhood (which laid the necessary foundations of our socialization), and the one of our adulthood (which is acquired by a voluntary act of possession, and I would add construction). The first home is the one that sees us grow up and leave. The second home, towards which we progressively move and which we are inspired to construct, is acquired and not imposed. It implies the idea of choice. These two homes are indissociable and inseparable. They constitute the totality of the being: the home, like the bearings to which we refer, and the home as a trajectory, a life to be created. 
sacrificial sheep after he married Marie. Some participants affirmed that it is sometimes the Moroccan partner that makes the longest "journey":

Emilia: When there is a couple like that, I think the person that compromises the most is the national, the person living in his/her own country. Because me, when I came here, I decided to come here and to change countries. Him, he changed countries practically without deciding to. That's because in this house he is not in Morocco. He has unconsciously left his society, too. Me, I left when I came [to Morocco], but he has also left in a way

(Emilia, is the fifty-seven year old Spanish wife of Anouar, who is a sixtyfour year old Moroccan, they have been together for thirty-eight years and have two children).

\section{Mixedness Resulting from a Trajectory of Mobility}

What is extremely interesting to note is that this movement away from the original references of a childhood home had already begun well before the romantic encounter of the couple. This finding led me to forge a second analytical metaphor: mixedness as a journey that begins well before the initial romantic encounter.

Analysis of the collected data shows that the mixed couples in this study (both the foreign partners and the Moroccans), had a common history of mobility that caused them to distance themselves in some way from their initial "home". Moreover, it is this history or disposition towards mobility that, in the majority of cases, originally enabled the couples to meet, by building bridges between individuals coming from very different backgrounds. Contrary to what one might think, the experience of marital mixedness is not therefore the beginning of self-distanciation, but rather a continuation of the mobility that started it.

The different pathways of mobility (the acquisition of intellectual and social capital, a prolonged stay in a foreign country, a conversion before meeting the partner, a marginal status, a multiplicity of social identifications, a drastic change in the family structure) will not be described in this article; I detail these elsewhere (Therrien, 2008), but I would like to give some examples of the most fascinating ones, as a means of illustrating what I mean by pathways of mobility.

During the analysis, I discovered that for over twenty-five people, their family structure had been disrupted before their romantic encounter, such as following the death of a parent, a divorce, or a war. Examples from this study clearly show that such a blow to the family structure caused a change in the individual's situation, setting them on a course of mobility. The example of Mohamed illustrates the effects of family breakdown on mobility.

Mohamed, a modest child, lived in a tiny village in southern Morocco. His father was recruited by the French army and then died in combat. His mother, not possessing the means to raise him properly, sent him to the military 
orphanage. He was educated, completing advanced studies in agronomic engineering, and then left for Germany where he was a student-intern. At the end of his internship, his employer gave him a sum of money with which he decided to travel. During his travels, he met a German woman who was staying in the same youth hostel as he was. She had been traveling with friends and was left stranded upon the construction of the Berlin Wall. Her return to the East being impossible, she lived in the youth hostel, far from her family. She and Mohamed met, got married and had five children. (Extract from my fieldnotes).

Analysis of different courses of mobility, illustrated by this example, clearly shows that mixedness is not the beginning of self-distanciation, but that it takes place within or comes from an experience of mobility. For many of the participants, it structured what I call a "habitus d'ailleurs ${ }^{13}$ ".

If we look closely at the life trajectories of the participants involved in this research, we can say that they had a pre-disposition for the "ailleurs".

François: My father was born in Viet Nam, my paternal grandmother travelled during her twenties. She was a writer. She was alone, single. She travelled all over the world... My paternal grandfather lived in Morocco, in Tunisia, in Viet Nam... My maternal grandfather comes from Chicago. My maternal grandmother comes from New York. They got married and settled in Montana. My mother went to live in France when she was eighteen. I was born in Paris. From my birth until I was eighteen years old, I lived in four or five different countries, and in eight different cities. So, as you can see, I had the pre-disposition to be on the move, you know!.

(François is twenty-seven years old, both French and American, and married without children).

"L'ailleurs", refers to mobility within a space and a distanciation from "home". Because of the pathways they have followed, the subjects in this study acquired a capital of mobility, not just geographically (within an area or space), but all sorts of mobility (intellectual, cultural, social, familial, and religious). They have certainly developed a facility for movement and living in different contexts, but above all they all had a pre-disposition for "l'ailleurs". We could say that these different paths of mobility caused them to acquire a "habitus d'ailleurs".

\section{Mixedness as Invitation to Experience Cultural Transformation}

As I mentioned at the beginning of this article, transposing the metaphor used by Fernandez of the extended journey (2002) seemed to me to be an original and contemporary way to portray this experience. It is necessary therefore, to verify that this metaphor is indeed reflected in the field data. This analytical

13. The term ailleurs in French broadly means "from elsewhere" or "from afar. 
step opened onto a third avenue of analysis: mixedness is a journey inviting mixed couples to open themselves up to cultural transformation.

The metaphor of the extended journey (Fernandez, 2002), briefly put, implies the idea that a journey leads to the discovery and awareness of "the other" and of the self. The journey (or mixedness in our case) has a destabilizing effect. It deconstructs and then reconstructs. It re-organizes our ways of conceiving our own identities (Lagnaoui, 1999). It leads to the re-evaluation of beliefs and contextual points of reference, the re-positioning of oneself, and the questioning of oneself about belonging (Begag and Chaouite, 1990). It is a source of enrichment and an impetus for self-reflection. This enrichment, however, is gained at a price: a degree of loss. We lose a piece of ourselves in the process, but once this loss is accepted, it is transformed into an unexpected resource: the enrichment of the self when coming into contact with "the other". The metaphor allows for movement when considering the framework of mixed couples, due mostly to the concepts of cultural transformation, alteration, and "congruence".

Cultural transformation (Guilbert, 1993) refers to a harmonization and reconciliation of one's original values with a completely different set of values. For example, it may involve adopting a new notion of time, of intimacy, modesty and decency, a different idea of respect, a sense of autonomy, gendered behaviour, different ways of perceiving poverty, different conceptions of family, and so forth. In this way, cultural transformation becomes a process of alteration of the self.

An excerpt from Francine's interview is a good example of cultural transformation:

Francine: In my everyday life, I have integrated a little bit of this way of functioning in a different manner, the fact of changing my mind at the last minute. That's something that was completely foreign to me and something that I still have trouble getting used to, but at the same time, it's something that is... that liberates your spirit and relieves you of stress until that moment and it's rather comfortable too. It means you have established something with someone. That generally doesn't happen, it brings about a flexibility... that means things can change without people holding it against you

(Francine is the thirty-six year old French wife of Salim, a thirty-eight year old Moroccan, they have been together eighteen years and have three children).

The concept of alteration (Fernandez, 2002) refers to the idea of a transformation when coming into contact with "the other". Taken in the sense of a reciprocal implantation of new habits, and not as the deterioration of old ones, this alteration implies that one can allow oneself to be deeply affected by the encounter with "the other", to the point where one accepts profound self-transformation.

The "congruence" (Fernandez, 2002) is the necessary fluidity of movement, of change and alteration. "Letting go" is crucial for the alteration to take place, and for the acceptance of movement. Fluidity does not thereby imply accepting 
just anything. Being all-accepting and all-tolerant, would mean committing oneself to nothing. If one never takes a position in losing onself in the perpetual movement, the consequence of becoming congruent with one's partner would therefore mean a total distancing from oneself. Cultural transformation implies that a balance must be created. A selection process must take place to decide what cannot be changed without compromising one's integrity, one's core principles, as well as deciding the things that are negotiable, the flexible peripheries (Begag and Chaouite, 1990).

How was this metaphor reflected in the course of the study? The data collected shows that the experience of mixedness is enticing and inviting to those who would engage themselves in an experience of cultural transformation. However, and this is where nuance comes into play, not all of the individuals responded to the invitation for transformation in the same way.

For some participants, cultural transformation was a desired change. They took part in a quest that changed and altered their being, a quest that was intensified by the experience of mixedness. For others, the cultural transformation was imposed. It was the result of the course of mixedness which pushed them to adopt certain elements, to transform some of their values. Some of them also resisted cultural transformation, convinced of the merits or even the superiority of their own values, and not wanting to permit the alteration or modification of these values.

\section{Migration as an Intensification of the Journey}

\section{Multiple and Movable Homes}

The last avenue of analysis returns to the idea that mixedness is a journey that intensifies with migration. I am very interested in the relationship between the migratory experiences of foreigners, and the ways that they come to define their own senses of "home" or personal identities. In analyzing this, we see that foreigners do not generally conceive of "home" as being connected to fixed roots (exclusive and territorial), instead they usually have multiple and movable points of attachment.

Home, therefore, is not tied to a particular geographic territory, but to connections with people, with memories, and with projections.

Shiraz: When we say "at home", it's not a question of land or country, it's the attachments, there are some things that bind us to this country. To the place where we are. [...] But here there are memories. That's what counts. It's not a question of buildings or trees, but of that which ties us to a country, it's the people, the love, the affective ties...

(Shiraz, fifty years old, is Iranian and married to Hassan, who is a sixty-three year old Moroccan. They have been together thirty years and have two children).

Home is not exclusive, either. It can be plural. These migrants have multiple homes, in multiple places. 
Question: And what about when you say at home?

Karla: Home is really here [talking about Morocco]. Home is also in Austria. Both are home. I don't have a problem with that. Here, I'm at home. Obviously! [...] It's here that I got married, it's here that I had my kids, it's here that I have my house, so it's here that I'm at home.

(Karla, who is a seventy-three year old Austrian, is the widow of Eussa, a Moroccan with whom she was married for twenty years and had two children).

The fact that home is not tied to a geographic location, and therefore not to a specific piece of land or patch of earth, attests to the idea of the deterritorialization of home. Since home is not linked directly to a specific area or piece of land, it becomes movable.

Question: Where is your home?

Rosalie: It's a difficult question for me. When people ask me: where do you come from? I have to ask: well, what do you want to know? Where I was born? Where I went to school? Where my parents live? Where my house is? What do you want to know? Ah, it's so difficult. We have moved so many times.

Question: And your roots?

Rosalie: I don't have any. I can't say my roots are here. And I don't miss that. I'm not sad about it...

Question: If I understand correctly, your roots are not necessarily associated with a place or to multiple places?

Rosalie: Yeah....they are not fixed to a place, I would say. Or to multiple places: I am practically displaceable. I don't have deep roots.

(Rosalie, is the sixty-four year old German wife of Mohamed, who is sixty-five. They are married, have been together for forty-two years, and have five children).

The fact that many of the participants spoke about Morocco as home illustrates that they have established connections in that country. For some, the attachments that they have established in Morocco have become even more important than the ones connected to their countries of origin. Some of them could never imagine leaving Morocco, and others even plan to be buried there.

Since the foreigners concerned in the study had many different ideas of home, many different home bases, it was intriguing to ask them, when possible, where they imagined being buried. Despite the seriousness of the topic, the light-heartedness of some of the responses was often disconcerting.

Question: And could you imagine yourself dying and being buried here?

Katia: Why not? What difference does it make where you die? My mother used to say, "I want to die and I want to be buried at home, on Russian soil". And I told her, "What difference is it to you, which worms eat you-Muslim worms or Orthodox worms? [laughs] It's the same thing". What's the difference? What's it going to change? What am I going to do there all by myself? Here I know plenty of people. I have my little life.

(Katia, a sixty-year old Russian is the widow of Ahmed, who was Moroccan, they were married and spent thirty years together, with two children) 
When we look at the range of answers given in response to this question, certain distinctions emerge: many of the foreigners could imagine themselves being buried in a country other than the one where they were born. For them, their place of burial did not necessarily coincide with a return to their native land. Having multiple homes, several of them imagined being buried in multiple places (and in that case cremation was the solution that several considered). Some were even concerned with offering more than one memorial site, in order to accommodate loved ones and friends in various locations. Very few individuals mentioned a connection to a community (religious or social), or to any particular ritual. Foreigners thought about their potential places of burial from an individual perspective, and not generally from a collective one. The lack of response from some individuals may demonstrate their uncertainties and indecisions. Being torn between multiple locations for one's own burial site is, in itself, an indication of the plurality of home. All of these points testify to the de-territorialization of self-identity, and the distance these foreigners have moved from their original senses of home.

\section{Conclusion}

As we have seen, this study presents a number of different arguments. In the first place, theoretical frameworks that have been elaborated with regards to conjugal mixedness are, for the most part, in some way outdated, especially when they do not take into account the movement that is at the heart of this contemporary experience. Secondly, writings on mixed couples within the Moroccan context are constrained by a negative discursive habitus. Thirdly, reservations persist within the Moroccan social context regarding mixed couples, and this social context continues to be disturbed by the mixedness that obliges the society to incorporate elements that do not conform to its traditional family model (endogamous and patriarchal). In view of these arguments, my ethnographic incursions into the lives of thirty mixed couples, and my own experiences of conjugal mixedness have permitted me to propose a new theoretical perspective, comparing mixedness to a prolonged journey.

Immersion in the daily lives of mixed couples also permits me to affirm that mixity is truly a journey, one that allows individuals to distance themselves from their childhood "homes" and to build their own trajectories. It is a journey that goes beyond cultural enrichment, inviting those it engages to let themselves be altered through close contact with difference. The journey is not limited to the experience of conjugal mixedness, as it is usually started well before the romantic encounter, at which point the journey is merely intensified by migration.

In a recent text, Varro (2012 forthcoming), invites us to be attentive to the context in which analytical reflections and concepts are developed, reminding us that theoretical currents have their own histories. Reflecting on the contributions of this study in the light of her article, I recognize that the emergence of my theoretical perspective, of the application of a metaphor of prolonged 
travel to the experience of conjugal mixedness, is in part linked to the context in which my research came to be, and in part to my own specific posture as a researcher.

It is worth highlighting, therefore, that Morocco's socio-political context favours and values North-South migrations over South-North migrations. The latter refer both to Morocco receiving sub-Saharan migrants and to Moroccans migrating to Europe, and being received on rather unequal terms. The fact that I am interested in conjugal mixedness within the Moroccan context, and therefore in couples in which the majority of foreign partners came from Northern countries (and for which the migratory experience carries positive connotations), has permitted the inversion of the dominant proposition concerning mixed couples (a call to value the positive aspects of mixedness).

My personal involvement in this line of study, the fact that I am myself a member of a mixed union in the Moroccan context, is evidently an important component of this project to create a new language for speaking about conjugal mixedness, that emphasizes movement and the positive aspects of such marriages. That this perspective is being proposed by a researcher who is personally involved in her subject of study is probably not surprising. While it can be uncomfortable for a social actor to feel confined by analytical avenues that reflect their personal life, it is equally inconceivable for an engaged researcher not to attempt to open up a space for recognition (Fabian, 2001).

Beate Collet (2004), who reflected on the question of personal involvements in one's own research, reminds us that one always has a subjective relation to the subject of study, even if one does not realize it. This personal relation, she adds, converges with the development of a research question, even influencing the posture of the researcher during investigation and analysis. She suggests that it is consequently preferable, to make these personal involvements clear by creating a distance and developing good theoretical tools. This has been intended in the theoretical framework of this study, by raising the question of proximity and distance in relation to the subject, clearly posed in my methodological approach, and by carrying out my own social analysis in order to demonstrate to others - as well as to myself - the point of view from which one is speaking.

If I were to do the social analysis of my own position, one would probably read that this new perspective (not on what is being observed and written, but on the method of observation and writing) is connected to a personal and professional project to demonstrate the positive potentials of mixedness. This point of view is admittedly an activist's stance, but the wealth of the ethnographic method is to constantly remind us that in spite of theoretical motivations, social reality is infinitely more complex. My ethnographic and personal immersion amidst mixed couples led me to represent in a nuanced fashion the fact that, while conjugal mixedness can be compared to a journey, it is evidently entangled in negotiations and points of ambivalence. It is certainly the intrinsic motivation of this study that this new perspective should contribute to the elaboration of a positive discursive habitus that values conjugal mixedness. 
Anthropology, in the words of Laplantine (2002), does not exist to comfort us, but to challenge current forms of expression. Its tone neither affirms, nor imposes meaning, instead expresses critical reflection and questioning. By suggesting this new perspective, this article seeks to go precisely in that direction.

\section{Bibliographic references}

AbDelghani, Houria (2001). «Le mariage mixte au jour le jour». Femmes du Maroc, July 2001, 55-62.

ADDIDOU, Fairouz (1990). Le couple mixte: époux marocain épouse étrangère au Maroc. (Master's thesis). Montréal: Université de Montréal.

AlAmi, Karine (2004). «Couples mixtes l'amour à haut risque». Famille actuelle, 38, 64-70.

Alemand, Sylvain (2004). «La mobilité comme capital». Sciences humaines. Voyage, migration, mobilité. 145, 20-22.

ApPADURAI, Arjun (1996). Modernity at Large: Cultural dimensions of globalization. Minnesota: University of Minnesota press.

ARKOUN, Mohamed (1977). «Les unions mixtes en milieu musulman». In: POLIAKOV, Léon (ed.), Le couple interdit. Entretiens sur le racisme. La dialectique de l'altérité socioculturelle et la sexualité. Paris: École des hautes études en sciences sociales, 75-87.

BACHELARD, Gaston (1957). La poétique de l'espace. Paris: PUF.

BARBARA, Augustin (1993). Les couples mixtes. Paris : Bayard.

BARRAUD, Émilie. 2008. «Femmes et famille en mutation. Dans le champ social de la kafala». In: GROUPE FEMMAGH (ed.). Les femmes face aux transformations socioéconomiques. Conflits, négociations et émergence de nouveaux rapports sociaux. Rabat: Centre Jacques Berque, recueil de textes (inédits).

BaUman, Zygmunt (2001). «Identity in the Globalizing World». Social Anthropology, 2 (9), 121-129.

BAUMAN, Zygmunt (1996). "From pilgrim to tourist or a short history of identity». In: HALL, Stuart and Du GAY, Paul. (eds.). Questions of Cultural Identity. London/ New Delhi: Sage Publications, 18-35.

BegaG, Azouz \& Chaouite, Abdellatif (1990). Écarts d'identité. Paris: Du Seuil.

Belarbi, Aïcha (1990). Couples en question. Casablanca: Le Fennec.

BEN GUIGA, M. (1993). Rapport sur l'expatriation matrimoniale des femmes françaises au Maghreb et en Afrique. Aspects sociaux et conséquences juridiques. Ministère marocain de la Justice.

Bensimon, Doris \& Lautman, Françoise (1975). «Quelques aspects théoriques des recherches concernant les mariages mixtes». Ethnies, 4, 17-40.

BenZAKOUR-Chami, Anissa (1990). «Le couple dans la littérature marocaine de langue française». In: BELARBI, Aïcha (ed.). Couples en question. Casablanca: Le Fennec, $137-158$.

BhabHa, Homi (1996). "Cultures in between». In: Hall, Stuart \& Du GuaY, Paul. (eds.). Questions of Cultural Identity. London/New Delhi: Sage Publications, 53-60.

BOUASRIA, Leïla (2008). «L'incidence du travail salarié sur les renégociations du rôle familial de l'ouvrière : cas de la femme ouvrière casablancaise dans les industries du textile». In Groupe FeMmaGH (ed.). Les femmes face aux transformations socioéconomiques. Conflits, négociations et émergence de nouveaux rapports sociaux. Rabat: Centre Jacques Berque, recueil de textes (inédits). 
BOUVIER, Pierre (1995). Socio-anthropologie du contemporain. Paris: Galilée

Breger, Rosemary \& Hill, Rosanna (1998). Cross-cultural marriage. Identity and choice. Oxford/New York: Berg

Chambers, Iain (1994). Migrancy, culture, identity. London /New York: Routledge.

Chbani Kunda, Hafsa (1990). Couples mixtes: un bonheur à haut risque. Casablanca: Eddif.

Clifford, James (1997). Routes. Travel and translation in the late twentieth century, Cambridge/London: Harvard University Press.

Collet, Beate \& Phillippe, Claudine (2008). Mixités. Variations autour d'une notion transversal. Paris: L'Harmattan.

COllet, Beate (2004). «De l'implication personnelle dans la recherche en sociologie: réflexion d'une immigrante en France vivant en couple mixte». In: PAPINOT, C; Lacourse, P \& Guichard-Claudic, Y. (eds). De Bretagne et d'ailleurs. Mélanges offerts à Anne Guillou. Brest: Université de Bretagne occidentale, 22-30.

Collet, Beate \& SANTElli, Emmanuelle (2003). "Comment repenser les mixités conjugales aujourd'hui? Modes de formation des couples et dynamiques conjugales d'une population française d'origine maghrébine». Revue Européenne des Migrations Internationales, 19, 51-79.

COTTRELl, Ann Baker (1990). "Cross-national marriages: a review of literature». Journal of Comparative Family Studies, 2 (XXI), 151-169.

DAÏF, Maria (2003). «Mariages mixtes. Le parcours du combattant». Tel Quel, 12-18 April 2003, 22-24.

Dan Rodriduez, Garcia (2006). «Mixed Marriages and Transnational Families in the Intercultural Context: A case study of African-Spanish couples in Catalonia». Journal of Ethnic Migration Studies, 3 (32), 403-433.

DÉJEUX, Jean (1989). Image de l'étrangère. Unions mixtes franco-maghrébines. Paris: La boîte à documents.

Delcroix, Catherine. (1993). «Oppositions et complémentarités des stratégies familiales. Mariages mixtes». Hommes et migration, 1167, 26-29.

DESRUISSEAUX, Jean-Claude (1990). "Mariages interculturels: piège social ou défi pluriculturel». Revue de l'Université de Moncton, 1/2 (23), 189-209.

Dugan, Romano (1997). Intercultural Marriage Promises and Pitfalls. Yarmouth, M.E: Intercultural Press.

FABIAN, Johannes (2001). «Remembering the Other: Knowledge and recognition». In: Fabian, Johannes. Anthropology with an Attitude: Critical essays. Stanford : Stanford University Press, 158-178.

FENOGLIO, Irène (1999). "A propos de la désignation "couple mixte"». In: LABAT, C \& Vermes, G. (ed.). Cultures, ouvertures, sociétés interculturelles. Du contact à l'interaction. Paris: l'Harmattan, 233-236.

FERNANDEZ, Bernard (2002). Identité nomade. De l'expérience d'Occidentaux en Asie. Paris: Anthropos.

GlicK-SCHILlER, Nina et al. (1995). «From Migrant to Transmigrant: Theorizing transnational migration». Anthropological Quaterly, 1 (65), 48-63.

GRIC (groupe de recherche islamo-chrétien de Rabat) (2003). «Le couple mixte installé au Maghreb». Prologues. La revue maghrébine du livre, 27/28, étélautomne 2003 : 111-124.

GUILBERT, Lucille (1993). «Transfert, transformation et transform culturel». Transferts orient-occident, populations, savoirs et pouvoirs. Sante-Foy : Université Laval (document du GERAC), 67-122. 
Gupta, A. \& Ferguson, J. (1992). «Beyond Culture: Space, identity and the politics of difference». Cultural Anthropology, 1 (7), 6-23.

Hannerz, Ulf (1996). Transnational Connections. Culture, people, places. London/ New York: Routledge, 17-29.

Hastrup, Kirsten (1995). A Passage to Anthropology. London /New York: Routledge.

Hoffman, Eva (1999). "The New Nomads». In: Aciman, André (ed.). Letters of Transit: Reflections on exiles, identity, language and lose. New York: The New York Press, 35-63.

ImAMURA, Anne E. (1990). «Strangers in a Strange Land: Coping with marginality in international marriage». Journal of Comparative Family Studies, 2 (21), 171-191.

KnAFOU, Remy (1998). La planète nomade. Les mobilités géographiques d'aujourd'hui. Paris: Berlin.

KRZYwKOWsKI, Dominique and DJAOUI, Elian (1975). «Mariages mixtes, sexualité, préjugés». Ethnies, 4, 117-134.

LagnaOUI, Ahmed (1999). Aux frontières de la tradition marocaine. Casablanca: Toubkal.

LAPLANTINE, François (2002). "L'anthropologie genre métis». In: GHASARIAN, C. (ed.). De l'ethnographie à l'anthropologie réflexive. Nouveaux terrains, nouvelles pratiques, nouveaux enjeux. Paris: Armand Collin,143-152,

LE BRIs, A. 2008. «Les mères célibataires au Maghreb». In: Groupe FEMMAGH (ed.). Les femmes face aux transformations socio-économiques. Conflits, négociations et émergence de nouveaux rapports sociaux. Rabat : Centre Jacques Berque, recueil de textes (inédits).

LTAIEF, Wassila (2005). "Conventions internationales, mariages mixtes et droit successoral en Afrique du nord: Cachez-moi cette différence que je ne saurais voir». Revue internationale des sciences sociales, 184, 363-383.

Manaf, A. (1990). Problèmes du couple mixte face au droit et à la société (cas francomarocain). Casablanca: Université Hassan II, Faculté de droit.

Marcus, Georges M. (1995). «Ethnography In/Of the World System: The emergence of multi-sited ethnography». Annual Review of Anthropology, 95-117.

Meintel, Deirdre \& LE GALL, Josiane (2008). "Unions mixtes en région et à Montréal: Thèmes et variations”. In: GeRMAIN, Annick; Leloup, Xavier \& RADICE, Martha (eds.). Les nouveaux territoires de l'ethnicité. Ste-Foy: Presses de l'Université Laval, 33-56.

MEINTEL, Deirdre et KAHN Emmanuel (2005). «De génération en génération: identités et projets identitaires des montréalais de deuxième génération». Ethnologies, 1 (27), 35-64.

MEINTEL, Deirdre (2002). «Transmitting pluralism: mixed unions in Montreal». Canadian Ethnic Studies/Études ethniques canadiennes, 3 (XXXIV), 99-120.

MONKACHI, Mohamed (1990). "Unions mixtes dans l'histoire du Maroc». Couples en question, 121-130, Casablanca.

NEYRAND, Gérard (1998). «Mariage, citoyenneté et intégration». Dialogue. Recherches cliniques et sociologiques sur le couple et la famille: ces couples qu'on appelle mixte, 65-75.

Philippe, Claudine (1999). «Les diverses approches adoptées par les chercheurs». In: LABAT, C \& Vermes, G. (eds.). Cultures ouvertures sociétés interculturelles. Du contact à l'interaction. Paris : l'Harmattan, 220-225.

Pineault, Nancy (2000). Couples endogames et couples mixtes: comparaison de la satisfaction conjugale, de la perception des pairs à l'égard du couple et de l'estime de soi. (Master's thesis). Sainte-Foy: Université Laval. 
Rocheron, Yvette (1999). «Les mariages mixtes: un indice anthropologique de l'assimilation». In: DEWITTE, Philippe (ed.). Immigration et intégration: L'Etat des savoirs. Paris: La Découverte, 205-211.

Root, Maria, P.P. (2001). Love's Revolution: Inter-racial Marriage. Philadelphia: Temple University Press.

SCHÜTZ, Alfred (2003.1944-45). L'étranger. Un essai de psychologie sociale suivi de l'homme qui rentre au pays. Paris: Allia.

SPICKARD, Paul R. (1989). Mixed Blood: Inter-marriage and ethnic identity in twentiethcentury America. Wisconsin: The University of Wisconsin Press.

STREIFF-FENART, Jocelyne (2000). «Sauver la face et réparer l'offense: le traitement rituel des mariages mixtes dans les familles maghrébines immigrées». In: AlBIER, Jean-Luc; OssipOW, Laurence; OUTEMZABET, Valérie \& WALDIS, Barbara (eds.). Mariages tous azimuts. Approche pluridisciplinaire des couples binationaux. Fribourg Suisse: Éditions universitaires de Fribourg Suisse, 175-189.

STREIFF-FENART, Jocelyne (1993). «Les immigrés et le marché matrimonial». In: BARROU, J \& HUU-KHOA, Le (eds.). L'immigration entre loi et vie quotidienne. Paris: L'Harmattan, 89-105.

STREIFF-FENART, Jocelyne (1989). Les couples franco-maghrébins en France. Paris: L'Harmattan.

TARriUs, Alain (2002). La mondialisation par le bas. Les nouveaux nomades de l'économie. Paris: Ballard.

THERriEN, C. (2008). «Frontières du " proche » et du « lointain » : pour une anthropologie de l'expérience partagée et du mouvement». Anthropologie et Sociétés, 32, $35-41$.

Tico, Marie-Claire (1998). «Les couples mixtes: transgresser et transmettre». Dialogue. Recherches cliniques et sociologiques sur le couple et la famille: ces couples qu'on appelle mixte, 139, 77-84.

VARrO, Gabrielle (2012). "Les couples mixtes à travers le temps. Une épistémologie de la mixité». Enfances, Familles, Générations (forthcoming).

VARRO, Gabrielle (2008). «Mettre la mixité à la place de l'origine». In: COLLET, Beate \& PHILIPpe, Claudine. (eds.). Mixités. Variations autour d'une notion transversale. Paris: L'Harmattan, 201-218.

VARro, Gabrielle (2003). Sociologie de la mixité. De la mixité amoureuse aux mixités sociales et culturelles. Paris: Berlin.

VARro, Gabrielle (1999). «Les futurs maîtres face à l'immigration. Le piège d'un habitus discursif». In: DAHLEM, Jacqueline \& VARro, Gabrielle. (coord.). Perspectives croisées sur l'Immigration. Paris ???: Mots/les langages du politique, 60, septembre : 30-42.

VARrO, Gabrielle (1995). Les couples mixtes et leurs enfants en France et en Allemagne. Paris: Armand Colin.

VINSONNEAU, Geneviève (1985). «Le couple mixte. Une situation psycho-sociale particulière». Cahiers de sociologie économique et culturelle, 3, 93-117.

WALDIS, B. and BRYON, R. (2006). Migration and Marriage: Heterogamy and homogamy in a changing world. Zûrich/Berlin: Lit Verlag. 